\title{
MORPHOLOGICAL VARIABILITY \\ OF JUNIPERUS PHOENICEA (CUPRESSACEAE) FROM THREE DISTANT LOCALITIES ON IBERIAN PENINSULA
}

\author{
MaŁGORZATA MAZUR ${ }^{1}$, KRYSTYNA BorATYŃSKA ${ }^{2}$, KATARZYNA MARCYSIAK ${ }^{3}$, \\ DANIEL GÓMEZ ${ }^{4}$, DOMINIK TOMASZEWSKI ${ }^{5}$, JAKOV DIDUKH ${ }^{6}$, ADAM BORATYŃSKI ${ }^{7}$ \\ 1,3 Pedagogic University, Institute of Biology and Environmental Conservation \\ Chodkiewicza 30, 80-064 Bydgoszcz, Poland \\ 1 e-mail: gosiadrz@ab-byd.edu.pl \\ 3 e-mail:marc@ab-byd.edu.pl \\ 2, 5, 7 Polish Academy of Sciences, Institute of Dendrology \\ Parkowa 5, 62-035 Kornik, Poland \\ 2 e-mail: borkrys@man.poznan.pl \\ 5 e-mail: dominito@man.poznan.pl \\ 7 e-mail: borata@man.poznan.pl \\ ${ }^{4}$ CSIC, Pyrenean Institute of Ecology \\ Avda. Regimiento de Galicia s/n, Apdo. 64, 22.700 Jaca (Huesca), Spain \\ e-mail: dgomez@ipe.csic.es \\ ${ }^{6}$ National Academy of Sciences of Ukraine, M.G. Kholodny Institute of Botany \\ 2, Tereschenkivska str., 01601 Kyiv, Ukraine \\ e-mail:didukh@botan.kiev.ua
}

(Recived: March 26, 2002. Accepted: January 9, 2003)

\begin{abstract}
The aim of the present study was biometrical comparison of three Iberian populations of Juniperus phoenicea, represented by the subsp. turbinata and subsp. phoenicea. Eight features of the cones and seeds, two of the shoots and leaves were studied.

The biometrical analysis of three distant populations of $J$. phoenicea shows great taxonomic distances among them. Two of them, representatives of J. phoenicea subsp. turbinata, are closer related each other than to the third, which represents J. phoenicea subsp. phoenicea. These results confirm the genetic differentiation of the taxons and also the biochemical and morphologic division of them. Nevertheless, the distances between particular populations are so great that more resemble the distances between species than between subspecies.
\end{abstract}

KEY WORDS: statistical analysis, biometry, juniper, cone, morphological differentiation, variability.

\section{INTRODUCTION}

Juniperus phoenicea $\mathrm{L}$. is a small tree, normally to 6-8 (11) $\mathrm{m}$ tall, or sometimes only a shrub, with scaly leaves and brown cones (Fig. 1-3). It occurs in southern Europe, south-west Asia and northern Africa (Fig. 4), but most frequently in the western part of the Mediterranean region. The species occupies costal dunes, maritime or somewhat inland slopes, but enters the mountain regions in the western part of their range, up to altitudes of $2400 \mathrm{~m}$ in Morocco and $1800 \mathrm{~m}$ in Spain. It grows in various types of Mediterranean forests and sometimes also forms pure stands (Quezel and Pessn 1980; Quezel and Barbero 1981; Browicz 1982; Quezel et al. 1992).
Juniperus phoenicea belongs to the section Sabina of the genus Juniperus. It is a variable species characterized by a great morphological and biochemical differentiation, which was the reason for distinguishing three subspecies (Greuter et al. 1984; Amaral Franco 1986; Lebreton and Rivera 1989).

Juniperus phoenicea L. Sp. Pl. 1039 (1953)

- subsp. phoenicea

- subsp. turbinata (Guss.) Nyman, Consp. Fl. Eur. 676 (1881)

Syn.: J. lycia L. Sp. Pl. 1039 (1753)

J. turbinata Guss. Fl. Sicul. Syn. 2: 634 (1845)

J. oophora G. Kunze, In: Flora (Regensburg) 29: 


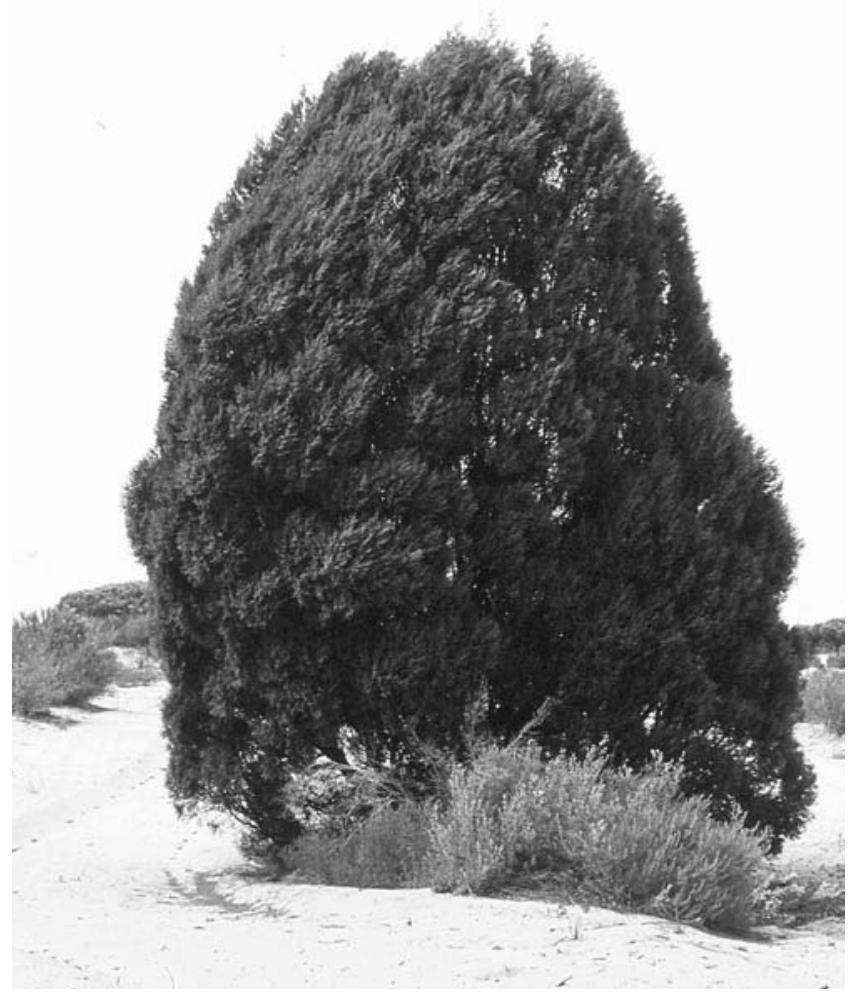

Fig. 1. Juniperus phoenicea tree about $9 \mathrm{~m}$ high; Spain, dunes in Matalascañas (Photo A. Boratyński).

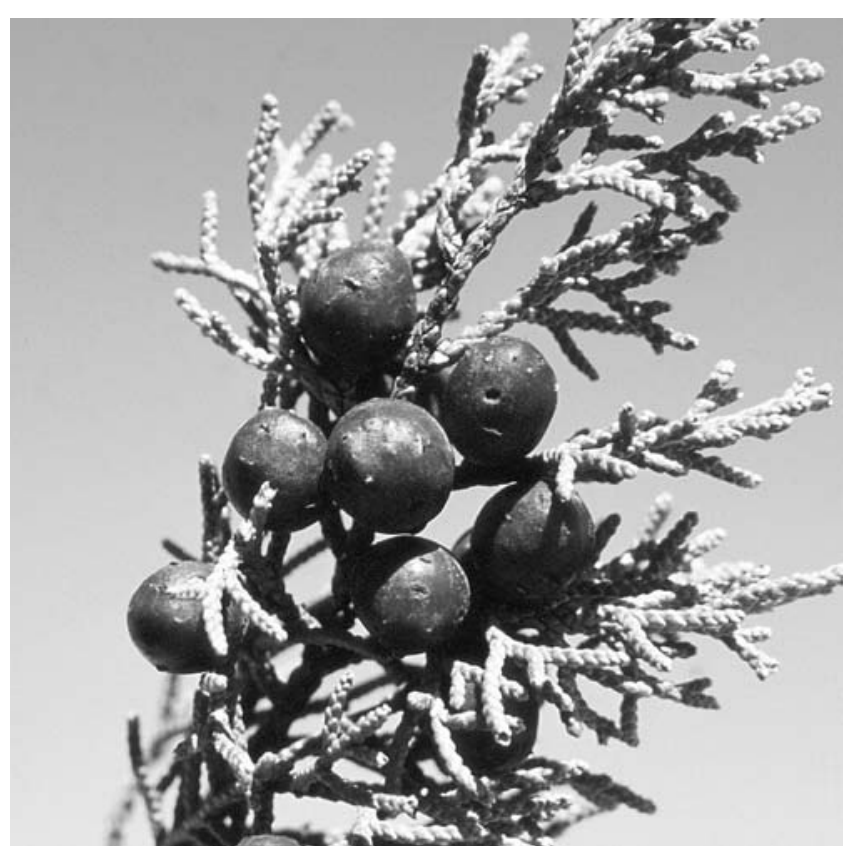

Fig. 2. Branch of Juniperus phoenicea with cones; Portugal, Cabo de Espichel (Photo A. Boratyński).

- subsp. mediterranea Lebreton et Thievend In: Naturalia Monspeliensia, Ser. Bot., 47: 8 (1981) (the most probably identical with subsp. turbinata).

In spite of the large morphological and biochemical variation described, Juniperus phoenicea has not been intensively studied. The only known biometric comparison of cones (Lebreton and Rivera 1989) was based on the material from single specimens sampled in many dispersed lo-

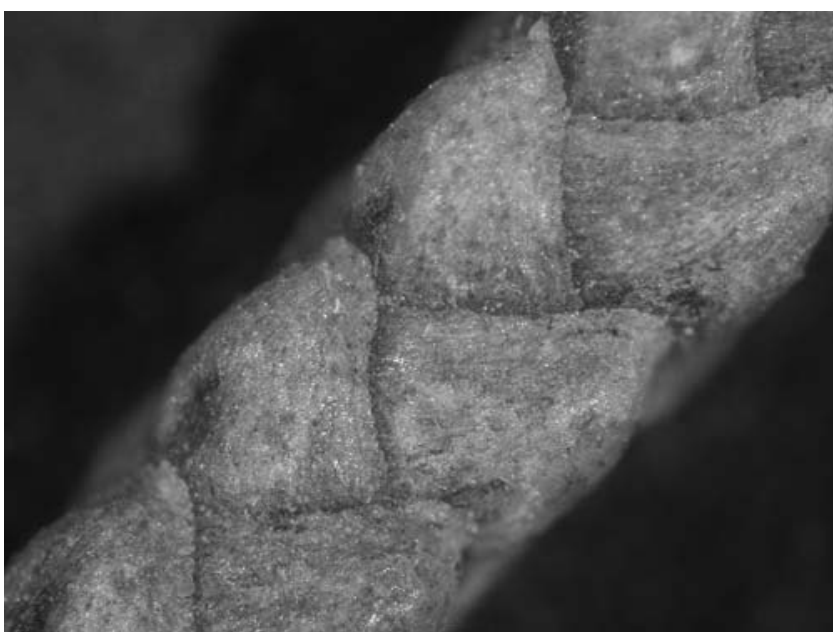

Fig. 3. Scaly-like leaves of Juniperus phoenicea (Photo D. Tomaszewski).

calities, mainly from west-Mediterranean regions. The results confirm the biochemical differences between the studied individuals and were the basis of morphological characteristics of the subsp. mediterranea and subsp. phoenicea (Lebreton and Thievend 1981; Lebreton 1983; Lebreton and Rivera 1989). The characters studied by them (weight, length and thickness of the cones and number of seeds) are very important from the taxonomic point of view. The other ones, as the shoots arrangement and leaves characters, are also considered to be important in distinguishing subspecies (Amaral Franco 1986).

Generally, the typical subspecies (subsp. phoenicea) is characterized by denser habit, more compact crowns, and more obtuse leaves and globose cones of 8-10 mm in diameter. The subsp. turbinata have more elongated and not so dense crowns, more acute leaves and ovoid cones about 12-14 mm in diameter (Amaral Franco 1986). The typical subspecies is distributed evenly in the area of the Iberian Peninsula, while the subsp. turbinata colonizes only maritime regions, mostly coastal dunes or maritime rocky slopes (Amaral Franco, 1.c.).

The aim of the present study was biometrical comparison of three populations of the species. Two of them are represented by the subsp. turbinata, probably identical with subsp. mediterranea described by Lebreton and Rivera (1989), and one by the typical subsp. phoenicea. The first particular aim was to verify if the maritime populations consist of individuals representing only subsp. turbinata or also specimens morphologically resembling typical subspecies. The contrary hypothesis, concerning the population of subsp. phoenicea from the continental part of Spain was examined too. Then the comparison of the studied subspecies was provided to define its morphological characters.

\section{MATERIAL AND METHODS}

The material for the present study has been collected on the Iberian Peninsula in September 1999 and comprises two subspecies distinguished there (Table 1). The samples of cones and small fragments of branches were gathered separately from every individual and then dried. The samples were collected from the sunny, mostly southern parts of the crowns (including the south-western and south-eastern expositions), from the height of 1.0-2.5 $\mathrm{m}$. The measure- 


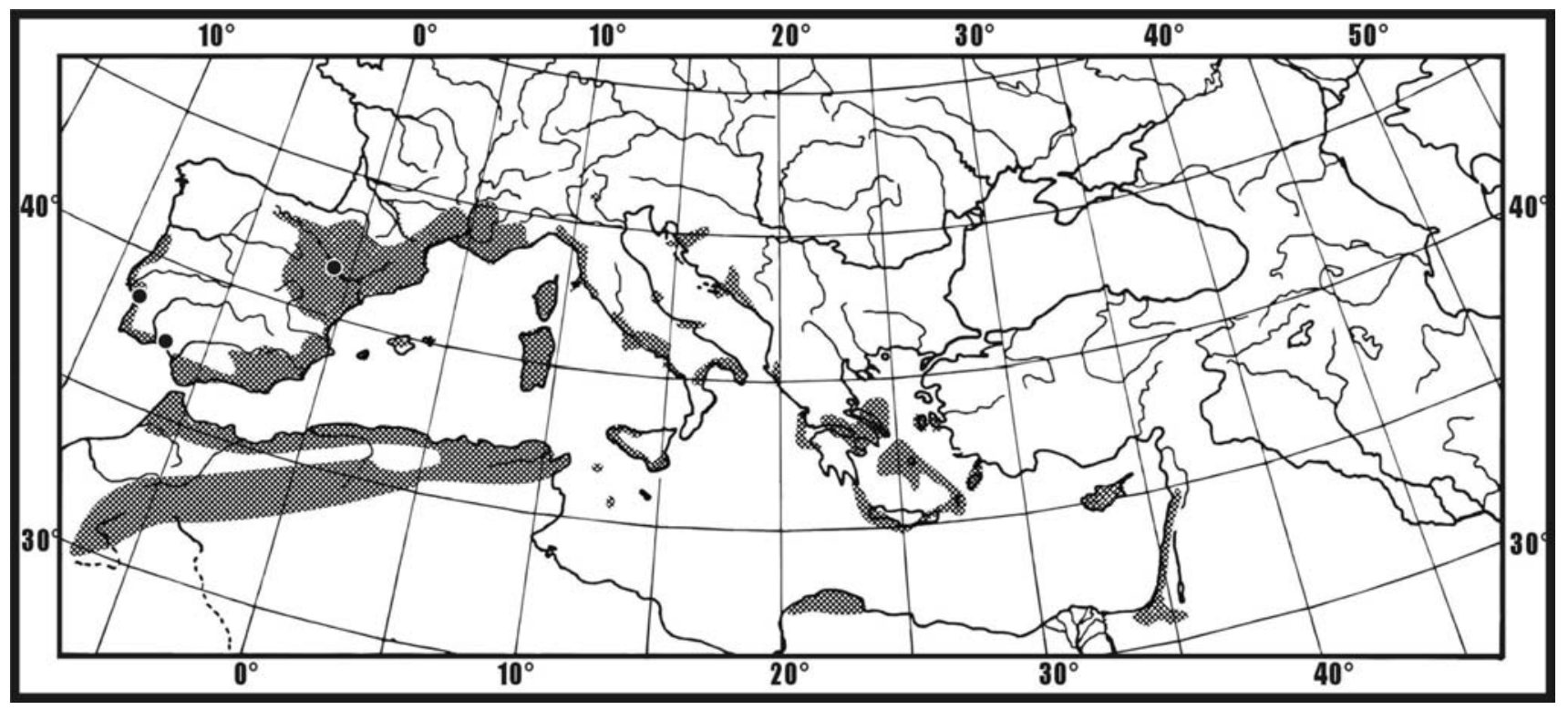

Fig. 4. Range of Juniperus phoenicea (drown by P. Kosiński after maps and data of Quezel and Santa 1962; Jalas and Suominen 1973; Fenaroli and Gambi 1976; Browicz 1982; Boratyński et al. 1992; Quezel et al. 1992).

TABLE 1. Localization of studied populations of Juniperus phoenicea.

\begin{tabular}{|c|c|c|c|c|c|c|}
\hline No & Locality & Subspecies & Spec. number & Longitude & Latitude & Altitude \\
\hline 1 & $\begin{array}{l}\text { Spain, Adalucía, Matalascañas, } \\
\text { forests on the dunes }\end{array}$ & turbinata (Guss.) Nyman & 28 & $6^{\circ} 31^{\prime} \mathrm{W}$ & $37^{\circ} 00^{\prime} \mathrm{N}$ & $10-20 \mathrm{~m}$ \\
\hline 2 & $\begin{array}{l}\text { Portugal, Estremadura, Cabo de Espichel, } \\
\text { coastal slopes }\end{array}$ & turbinata (Guss.) Nyman & 27 & $9^{\circ} 46^{\prime} \mathrm{W}$ & $38^{\circ} 30^{\prime} \mathrm{N}$ & $40-50 \mathrm{~m}$ \\
\hline 3 & $\begin{array}{l}\text { Spain, Aragón, Nueno (Huesca), Salto de Roldán, } \\
\text { near Santa Eulalia de la Peńa }\end{array}$ & phoenicea & 27 & $0^{\circ} 25^{\prime} \mathrm{W}$ & $42^{\circ} 17^{\prime} \mathrm{N}$ & $1000 \mathrm{~m}$ \\
\hline
\end{tabular}

ment was done in 2001 on dry material. The cones, shoots and seeds were measured with accuracy to $0.1 \mathrm{~mm}$. The populations were characterized on the basis of 27-28 individuals. Ten ripen cones and ten short fragments of one-year old shoots of the last ramification were sampled from the 89 individuals, and consequently, a total of 890 values of each of the characters examined were analysed statistically. Each individual was analysed separately, and later the three local samples and two subspecies were analysed together. Eight features of the cones and seeds, two of the shoots and leaves and four proportions were studied (Table 2).

The measurements and evaluation of the data were taken under the stereoscope microscope of $8 \times$ magnification with a scaled ocular. The data obtained were statistically analysed with the STATISTICA 5.1 software. Arithmetic means, standard deviations and variation coefficients were calculated for every feature. The interaction between particular characters was tested using the Pearson's linear correlation coefficient. A discrimination analysis was performed and the position of the specimens was examined along with the first discriminant variables inside particular populations studied to check their homogeneity.

The distribution of individuals in the two main variables were tested to verify the distance among them, among the populations studied and between the subspecies compared. The dendrogram of the shortest Euclidean distances among the populations studied were constructed (Marek 1989; Morrison 1990; Underwood 1997, Moczko et al. 1998).

\section{RESULTS}

Mean values, ranges, standard deviations and variation coefficients are presented for every sample separately and for all individuals combined (Table 3). The greatest differences between mean values of particular features of the compared populations are observed in the number of recta (character 1) and number of seeds per cone (character 6).

TABLE 2. Analysed characters of the cones, seeds, shoots and leaves.

\begin{tabular}{ll|c}
\hline No & Characters & Accuracy and measure \\
\hline 1 & Number of recta (4 or 6) & Specimen \\
2 & Length of cone & $0.1 \mathrm{~mm}$ \\
3 & Width of cone & $0.1 \mathrm{~mm}$ \\
4 & Thickness of cone & $0.1 \mathrm{~mm}$ \\
5 & Cone scale number & Specimen \\
6 & Number of seeds & Specimen \\
7 & Length of seed & $0.1 \mathrm{~mm}$ \\
8 & Width of seed & $0.1 \mathrm{~mm}$ \\
9 & Number of leaves on the 5 mm & Specimen \\
& of the last ramification shoot & $0.1 \mathrm{~mm}$ \\
10 & Thickness of the last ramification & \\
& shoot with leaves & \\
11 & Ratio of cone length/wide (2/3) & \\
12 & Ratio of cone length/thickness (2/4) & \\
13 & Ratio of seed length/width (7/8) & \\
14 & Ratio of cone width/number & \\
& of seeds (3/6)
\end{tabular}




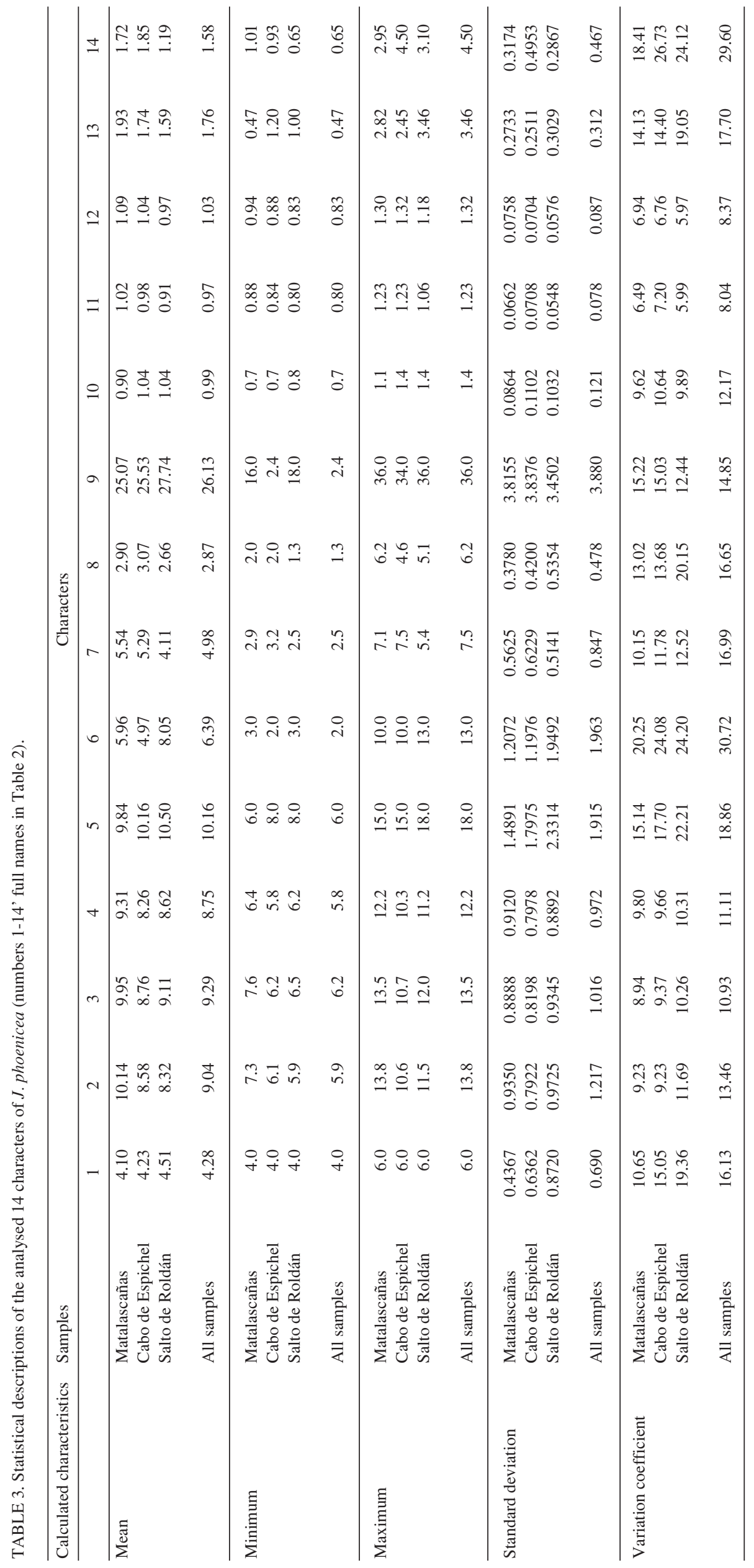

The most variable feature was the number of seeds in a cone (character 6) with a variation coefficient of more than $30 \%$ in all three populations, but about $20-24 \%$ in particular populations. The most stable characters appear to be the shape of a cone measured as ratio of length/width and length/ thickness (characters 11 and 12), which attain a variation coefficient of about $8 \%$ for all populations together, but vary at $6-7 \%$ when examined separately (Table 3 ).

The correlation between many features is statistically significant at level $p>0.01$. The numbers of correlations and the correlated characters are different in the particular populations and in all populations together (compare Table 4-7). Some characters in one population are strongly correlated, while in others the correlations are slight and insignificant. It indicates that differentiation of specimens is different within each sampled population.

The most strongly correlated features are the length (character 2), width (character 3) and thickness (character 4) of a cone. Also the number of recta (character 1) correlates with number of cone scales (character 5), number of seeds in a cone (character 6) and cone dimensions with number of cone scales (characters 2-5).

The number of leaves on the 5 $\mathrm{mm}$ of shoot (character 9) and thickness of shoot with leaves (character 10) are inversely more or less strongly correlated with the features of the cone and seeds (Tables 4-7), but not in every population studied.

The homogeneity of samples was tested with analysis of discriminant function for every sampled population separately. The intrapopulation variations of individuals in the samples from Matalascañas and Cabo de Espichel were weak (Fig. 5 and 6). The greatest discriminating power in the population from Matalascañas has the cone scale number (character 5) and the seed length/width ratio (character 13) characterized by the Wilks' lambda value of 0.354 and 0.44 , respectively. The first main variable $\left(U_{1}\right)$ includes $\pm 61 \%$ of the whole variability and is deter- 
TABLE 4. Correlation coefficients between characters of Juniperus phoenicea from Matalascañas. * - significance at level $\mathrm{p}=0.05 ; * *-$ significance at level $\mathrm{p}=0.01$ (character numbers as in Table 2).

\begin{tabular}{|c|c|c|c|c|c|c|c|c|c|}
\hline 2 & 0.04 & & & & & & & & \\
\hline 3 & 0.02 & $0.81 * *$ & & & & & & & \\
\hline 4 & 0.05 & $0.79 * *$ & $0.96 * *$ & & & & & & \\
\hline 5 & $0.40 *$ & 0.04 & 0.24 & 0.25 & & & & & \\
\hline 6 & 0.20 & 0.21 & 0.32 & $0.39 *$ & 0.33 & & & & \\
\hline 7 & 0.20 & $0.79 * *$ & $0.71 * *$ & $0.61 * *$ & -0.02 & -0.08 & & & \\
\hline 8 & -0.19 & 0.28 & $0.40 *$ & $0.38 *$ & -0.10 & 0.00 & 0.19 & & \\
\hline 9 & -0.12 & $-0.44 *$ & -0.27 & -0.24 & -0.17 & -0.13 & -0.25 & -0.27 & \\
\hline 10 & 0.18 & -0.06 & -0.05 & -0.13 & 0.21 & 0.20 & 0.03 & $-0.42 *$ & 0.04 \\
\hline Characters & 1 & 2 & 3 & 4 & 5 & 6 & 7 & 8 & 9 \\
\hline
\end{tabular}

TABLE 5. Correlation coefficients between characters of Juniperus phoenicea from Cabo de Espichel. * - significance at level $\mathrm{p}=0.05$; ** significance at level $\mathrm{p}=0.01$ (character numbers as in Table 2).

\begin{tabular}{|c|c|c|c|c|c|c|c|c|c|}
\hline 2 & -0.03 & & & & & & & & \\
\hline 3 & 0.13 & $0.71 * *$ & & & & & & & \\
\hline 4 & 0.17 & $0.77 * *$ & $0.98 * *$ & & & & & & \\
\hline 5 & $0.73 * *$ & 0.33 & 0.27 & 0.35 & & & & & \\
\hline 6 & 0.21 & 0.21 & 0.34 & 0.35 & 0.38 & & & & \\
\hline 7 & 0.02 & $0.67 * *$ & $0.66 * *$ & $0.69 * *$ & 0.35 & 0.23 & & & \\
\hline 8 & -0.04 & $0.49 * *$ & $0.46^{*}$ & $0.50 * *$ & 0.20 & -0.30 & $0.43 *$ & & \\
\hline 9 & -0.05 & $-0.41 *$ & $-0.48 *$ & $-0.50 * *$ & -0.33 & -0.08 & $-0.39 *$ & $-0.43 *$ & \\
\hline 10 & -0.17 & 0.16 & 0.14 & 0.11 & 0.09 & 0.05 & 0.24 & 0.12 & -0.24 \\
\hline Characters & 1 & 2 & 3 & 4 & 5 & 6 & 7 & 8 & 9 \\
\hline
\end{tabular}

TABLE 6. Correlation coefficients between characters of Juniperus phoenicea from Salto de Roldán. * - significance at level p $=0.05$; ** - significance at level $\mathrm{p}=0.01$ (character numbers as in Table 2).

$\begin{array}{cccccccccc}2 & 0.22 & & & & & & & \\ 3 & 0.24 & 0.90^{* *} & & & & & & \\ 4 & 0.22 & 0.91^{* *} & 0.99^{* *} & & & & & \\ 5 & 0.65^{* *} & 0.59^{* *} & 0.59^{* *} & 0.57^{* *} & & & & \\ 6 & 0.17 & 0.49^{* *} & 0.53^{* *} & 0.55^{* *} & 0.52^{* *} & & & \\ 7 & 0.27 & 0.78^{* *} & 0.70^{* *} & 0.72^{* *} & 0.44^{*} & 0.12 & & \\ 8 & 0.30 & 0.13 & 0.13 & 0.17 & 0.09 & -0.17 & 0.39^{*} & -0.43^{*} \\ 9 & -0.35 & -0.08 & -0.17 & -0.17 & -0.06 & 0.06 & -0.29 & -0.42^{*} \\ 10 & 0.32 & 0.28 & 0.39 * & 0.32 & 0.49^{*} & 0.01 & 0.36 & 0.12 & 9\end{array}$

TABLE 7. Correlation coefficients between characters of Juniperus phoenicea from all populations sampled. * - significance at level p $=0.05$; ** - significance at level $\mathrm{p}=0.01$ (character numbers as in Table 2).

$\begin{array}{cccccccccc}2 & -0.30^{* *} & & & & & & & \\ 3 & -0.07 & 0.84^{* *} & & & & & & \\ 4 & -0.03 & 0.81^{* *} & 0.98^{* *} & & & & & \\ 5 & 0.68^{* *} & -0.02 & 0.15 & 0.19 & & & & \\ 6 & 0.45^{* *} & -0.11 & 0.21 & 0.26^{* *} & 0.41^{* *} & & & \\ 7 & -0.41^{* *} & 0.73^{* *} & 0.47^{* *} & 0.43^{* *} & -0.13 & -0.61^{* *} & & \\ 8 & -0.15 & 0.23^{* *} & 0.12 & 0.14 & -0.03 & -0.54^{* *} & 0.54^{* *} & -0.50^{* *} \\ 9 & 0.11 & -0.43^{* *} & -0.31^{* *} & -0.29^{* *} & 0.00 & 0.34^{* *} & -0.55^{* *} & 0.09 \\ 10 & 0.37^{* *} & -0.53^{* *} & -0.34^{* *} & -0.33^{* *} & 0.37^{* *} & 0.17 & -0.36^{* *} & -0.04 & 8\end{array}$

mined mostly by cone scale number (character 5), while the second main variable $\left(\mathrm{U}_{2}\right)$ covers $29 \%$ of the variation and is determined by seed length/width ratio (character 13).

The greatest discriminating power in the population from Cabo de Espichel has the cone length/width ratio (character 11) and cone width (character 3), with Wilks' lambda 0.396 and 0.463 , respectively. The two first main variables are responsible for $100 \%$ of variation (Fig. 6). The first main variable $\left(\mathrm{U}_{1}\right)$ is influenced mostly by cone length/wide ratio (character 11$)$ and the second variable $\left(\mathrm{U}_{2}\right)$ by width of cone (character 3 ).

The population from Salto de Roldán has a quite different type of variation. The two first main variables cover only $49 \%$ of variation. For this reason it was analysed in the space of the first three main variables, which are responsible for $62 \%$ of variation (Fig. 7). All individuals form one group. The first main variable $\left(\mathrm{U}_{1}\right)$ is determined mostly by number of leaves (character 9), cone width (character 3 ) and cone thickness (character 4); the second main variable $\left(\mathrm{U}_{2}\right)$ also by character 3,4 and 9 , and the third main variable $\left(\mathrm{U}_{3}\right)$ by cone length/wide ratio (character 11).

The analysis of discriminating function for all three samples together showed that the most important in the distinguishing of individuals from particular populations were the length of seeds (character 7) (particular Wilks' lambda value of 0.55 ), the thickness of the last ramification shoot 


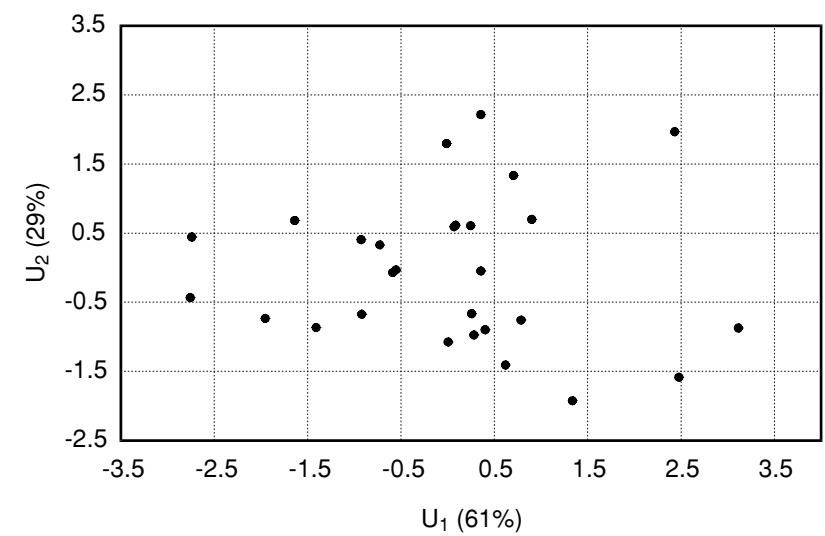

Fig. 5. Result of discriminant analysis based on 14 characters of cone and needle of Juniperus phoenicea subsp. turbinata from Matalascañas plotted along the two first discriminant variables $U_{1}$ and $U_{2}$, which accounted for $90 \%$ of the total variation.

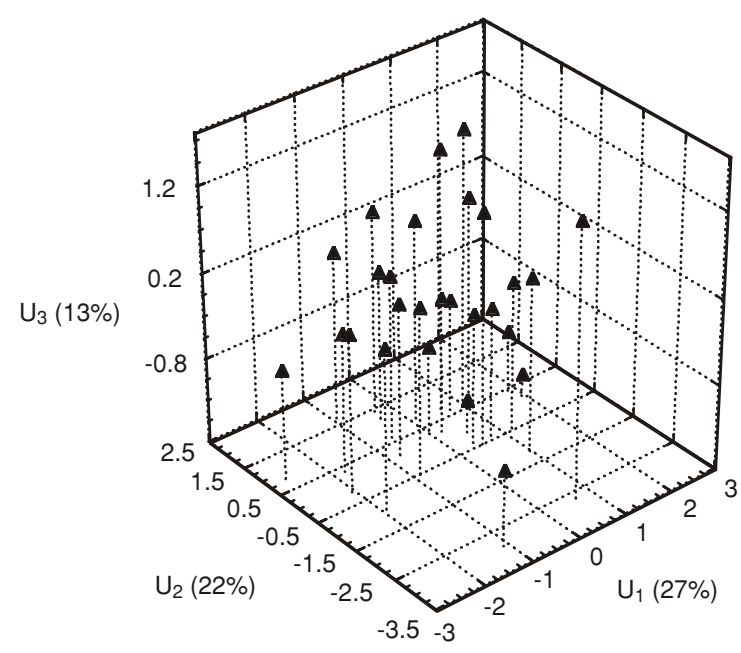

Fig. 7. Result of discriminant analysis based on 14 characters of cone and needle of Juniperus phoenicea subsp. phoenicea from Salto de Roldán plotted along the three first discriminant variables $U_{1}, U_{2}$, and $U_{3}$ which accounted for $62 \%$ of the total variation.

with leaves (character 10 with particular Wilks' lambda 0.67 ) and length of cone (character 2 with particular Wilks' lambda 0.68). All specimens sampled from particular populations form three distinguished groups (Fig. 8) in the space of two main variables responsible for $100 \%$ of whole variation. The first main variable $\left(\mathrm{U}_{1}\right)$ is determined mostly by characters $7,6,14,11$ and 2 , and $U_{2}$ by characters 10,2 and 6.

The population from Salto de Roldán, with Juniperus phoenicea subsp. phoenicea, is the most distinct one and forms a separate group. This population differs more strongly from the two others in the distance determined by the first main variable $\left(\mathrm{U}_{1}\right)$, responsible for $72 \%$ of variation. The populations of $J$. phoenicea subsp. turbinata are much more weakly differentiated, mostly in the distance determined by the second main variable $\left(\mathrm{U}_{2}\right)$ responsible for $28 \%$ of total variation. In all three populations single specimens are of intermediate character (Fig. 8).

The closest Euclidean distances between particular specimens agglomerate them in three main groups (Fig. 9). The first one consists of conglomeration of subgroups which include specimens from the two populations of Juniperus

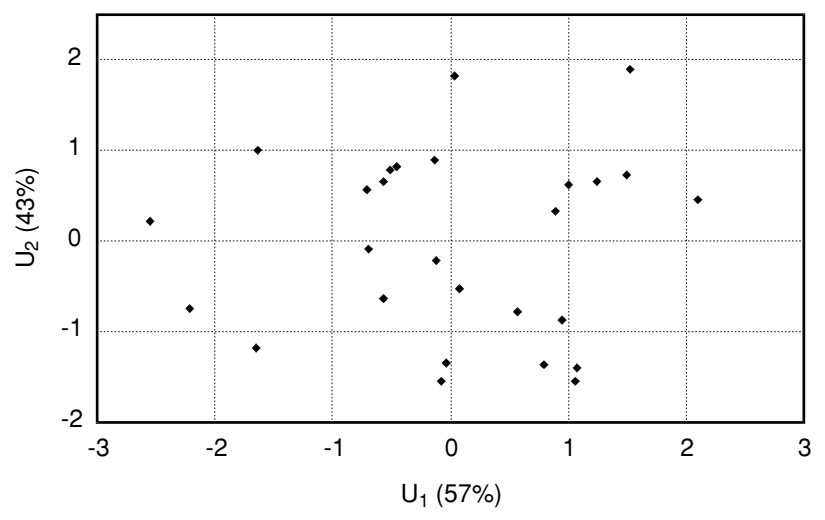

Fig. 6. Result of discriminant analysis based on 14 characters of cone and needle of Juniperus phoenicea subsp. turbinata from Cabo de Espichel plotted along the two first discriminant variables $U_{1}$ and $U_{2}$, which accounted for $100 \%$ of the total variation.

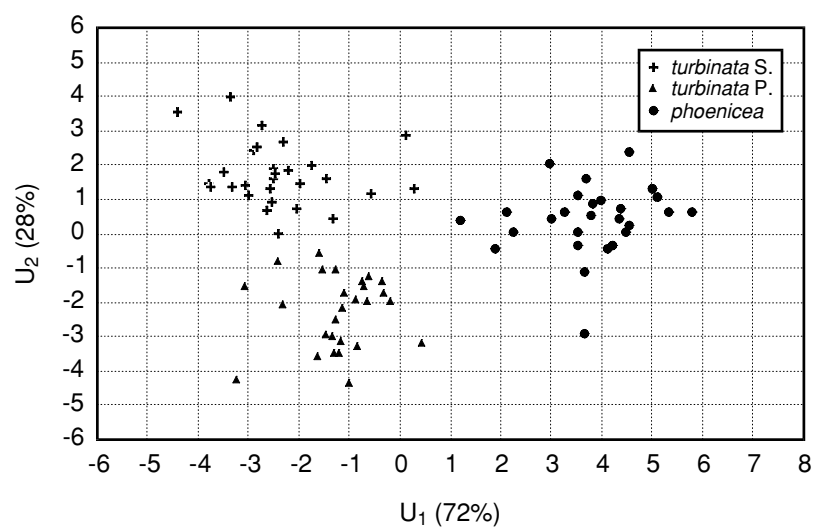

Fig. 8. Result of discriminant analysis based on 14 characters of cones and needles of the two populations of Juniperus phoenicea subsp. turbinata from Matalascañas (•) and Cabo de Espichel $(\bullet)$ and 1 population of Juniperus phoenicea subsp. phoenicea from Salto de Roldán (ム) plotted along the two first discriminant variables $U_{1}$ and $U_{2}$, which accounted for $100 \%$ of the total variation ( $\mathrm{S}-$ Spain, $\mathrm{P}-$ Portugal).

phoenicea subsp. turbinata with 4 specimens from subsp. phoenicea. The second group is divided into 2 large subgroups, the first one consists of individuals from the population from Salto de Roldán (Juniperus phoenicea subsp. phoenicea) with 2 specimens from the population from Matalascañas ( $J$. phoenicea subsp. turbinata). The second subgroup includes specimens from Matalascañas and Cabo de Espichel (J.phoenicea subsp. turbinata). It can be concluded that the two populations collected as representing subsp. turbinata are heterogenic and consist of more or less distant groups of very closely related individuals. The specimens from the population from Salto de Roldán (J. phoenicea subsp. phoenicea) are more closely related and almost all form one large group.

The agglomeration on the basis of mean values for 3 analysed populations (Fig. 10) shows closer relations between those representing $J$. phoenicea subsp. turbinata than between J. phoenicea subsp. phoenicea.

\section{DISCUSSION AND CONCLUSIONS}

The biometrical analysis of three distant populations of Juniperus phoenicea from the Iberian Peninsula shows gre- 


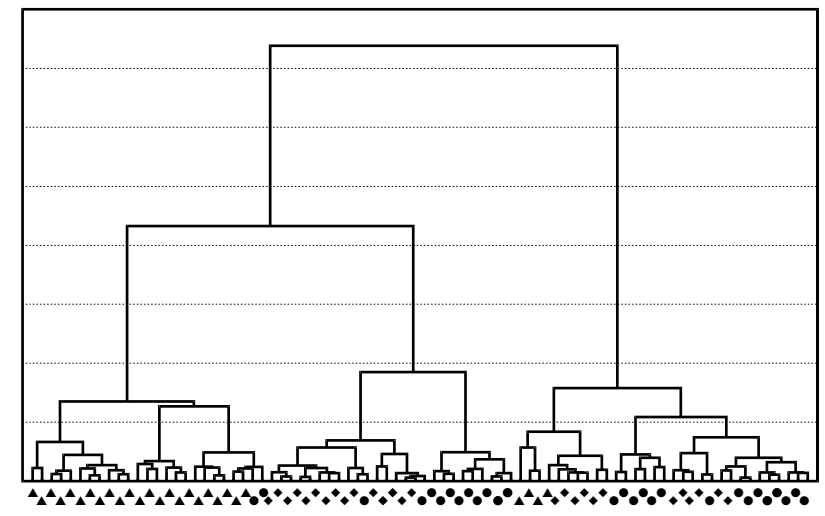

Fig. 9. Dendrograms of all individuals of Juniperus phoenicea subsp. turbinata from Matalascañas (•) and Cabo de Espichel $(\bullet)$ and of Juniperus phoenicea subsp. phoenicea from Salto de Roldán (ム) constructed according to Ward Method.

at taxonomic distances among them. The differentiation done on the basis of the 10 measured and 4 additional calculated features is manifested in large Euclidean distances between all analysed populations. Two of them, representatives of $J$. phoenicea subsp. turbinata, are closer related each other than to the third, which represents $J$. phoenicea subsp. phoenicea. These results confirm the genetic differentiation of the taxons (Lewandowski et al. 2000) and also the biochemical and morphologic division of them (Lebreton and Thievend 1981; Lebreton 1983; Lebreton and Rivera 1989). Nevertheless, the distances between particular populations are so great that they more resemble the distances between species than between subspecies.

The great differences between particular populations are manifested by the majority of individuals representing them. Only single specimens from subsp. turbinata were found to be joined into the group of subsp. phoenicea (Fig. 9). Also only 4 individuals from the population of subsp. phoenicea fall into the group of subsp. turbinata. It shows a different origin or a long isolation of the two subspecies.

The differences between two populations of subsp. turbinata are also manifested on the high level (Fig. 10), however, many individuals from the two populations examined are of intermediate character. It can also be explained by isolation for a long time, but probably the same origin.

\section{LITERATURE CITED}

AMARAL FRANCO J. do 1986. Juniperus L. In: Flora iberica. Castroviejo S., Laínz M., López González G., Montserrat P., Muñoz Garmendia F., Paiva J., Villar L. (eds.). Real Jardín Botánico, CSIC, Madrid, Vol. 1, pp. 181-188

BORATYŃSKI A., BROWICZ K., ZIELIŃSKI J. 1992. Chorology of trees and shrubs in Greece. Polish Academy of Science, Institute of Dendrology, Sorus, Poznań-Kórnik. 286 pp.

BROWICZ K. 1982. Chorology of Trees and Shrubs in SouthWest Asia and Adjacent Regions. PWN, Warszawa-Poznań, Vol. 1, $172 \mathrm{pp}$

FENAROLI L., GAMBI G. 1976. Alberi. Museo Tridentino di Scienze Naturali, Trento, $717 \mathrm{pp}$.

GREUTER W., BURDET H.M., LONG G. 1984. Med-Checklist. Conservatoire et Jardin Botaniques de la Ville de

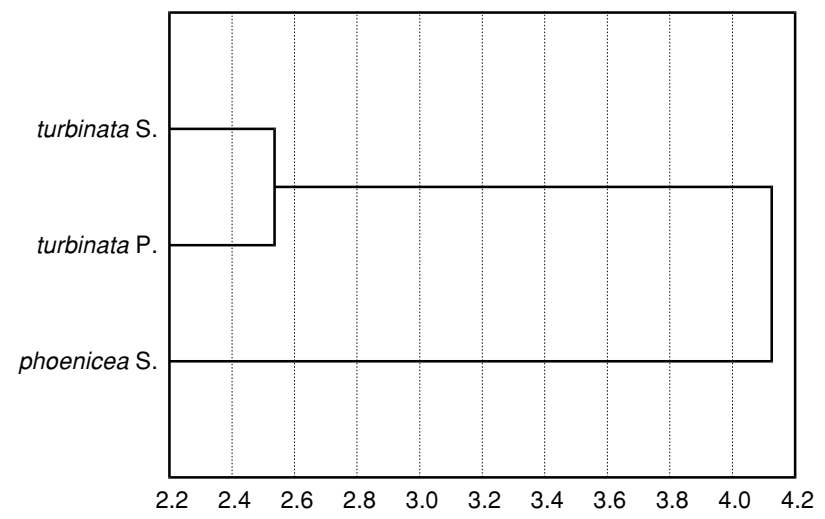

Fig. 10. Dendrograms of populations of Juniperus phoenicea subsp. turbinata and Juniperus phoenicea subsp. phoenicea constructed according to Single Linkage Method (S - Spain, P - Portugal).

Genève et Med-Checklist Trust of OPTIMA. Genève, Vol. 1, 330 pp. + 1-C.

JALAS J., SUOMINEN J. 1973. Atlas Florae europaeae. 2. The Committee for Mapping the Flora of Europe and Societas Biologica Fennica Vanamo, Helsinki. 40 pp.

LEBRETON P. 1983. Nouvelles données sur la distribution au Portugal et en Espagne des sous-espèces du Genévrier de Phénicie (Juniperus phoenicea L.). Agron. lusit. 42: 55-62.

LEBRETON P., RIVERA D. 1989. Analyse du taxon Juniperus phoenicea $\mathrm{L}$. sur des bases biochimiques et biométriques. Naturalia monspeliensia, Sér. Bot. 53: 17-41.

LEBRETON P., THIEVEND S. 1981. Sur une sous-espèce du Genévrier de Phénicie Juniperus phoenicea L., definie a partir de criteres biochimiques. Naturalia monspeliensia, Sér. Bot. 47: 1-12.

LEWANDOWSKI A., BORATYŃSKI A., MEJNARTOWICZ L. 2000. Allozyme investigations on the differentiation between closely related pines - Pinus sylvestris L., P. mugo Turra, $P$. uncinata Ramond ex DC. and P. uliginosa Neumann (Pinaceae). Plant Syst. Evol. 221: 15-24.

MAREK T. 1989. Analiza skupień empirycznych. PWN, Warszawa, $47 \mathrm{pp}$.

MOCZKO A.J., BRĘBOROWICZ G.H., TADEUSIEWICZ R. 1998. Statystyka w badaniach medycznych. PWN, Warszawa, $122 \mathrm{pp}$.

MORRISON D.F. 1990. Wielowymiarowa analiza statystyczna. PWN, Warszawa, $589 \mathrm{pp}$.

QUEZEL P., SANTA S. 1962. Nouvelle Flore de l'Algérie. 1. Editions du Centre National de la Recherche Scientifique, Paris. $565 \mathrm{pp}$.

QUEZEL P., BARBERO M. 1981. Contribution à l'étude des formations pré-steppiques à Genévriers au Maroc. Bol. Soc. Broteriana 53 (2): 1137-1160.

QUEZEL P., PESSN P. 1980. Biogéographie et ecologie des conifers sur le pourtour méditerranéen. Actualités d'ecologie forestière. Gauthier-Villars, Paris, pp. 205-255.

QUEZEL P., BARBERO M., BENABID A., RIVASMARTÍNEZ S. 1992. Contribution à l'étude des groupements forestiers et preforestiers du Maroc oriental. Studia Bot. 10: 57-90.

UNDERWOOD A.J. 1997. Experiments in Ecology. Cambridge University Press. Cambrigde, 504 pp. 


\section{ZMIENNOŚĆ MORFOLOGICZNA \\ JUNIPERUS PHOENICEA (CUPRESSACEAE) \\ Z TRZECH ODLEGŁYCH POPULACJI NA PÓŁWYSPIE IBERYJSKIM}

\section{STRESZCZENIE}

Celem przedstawionych badań było porównanie cech biometrycznych trzech iberyjskich populacji Juniperus phoenicea reprezentowanych przez subsp. turbinata i subsp. phoenicea. Przebadano osiem cech szyszkojagód i nasion i dwie dotyczące pędów i liści.

Analiza biometryczna trzech populacji $J$. phoenicea wskazuje na istnienie znacznej odległości taksonomicznej między nimi. Dwie z nich, reprezentujące $J$. phoenicea subsp. turbinata, są bardziej zbliżone do siebie niż do trzeciej populacji, której osobniki należą do J. phoenicea subsp. phoenicea. Wyniki te potwierdzają nie tylko genetyczne zróżnicowanie tych taksonów, ale także ich biochemiczną i morfologiczną odrębność. Odległości pomiędzy poszczególnymi populacjami są tak duże, że bardziej przypominają relacje między gatunkami niż podgatunkami.

Znaczne różnice pomiędzy populacjami wykazuje większość osobników je tworzących. Jedynie pojedyncze egzemplarze subsp. turbinata zaliczono do grupy subsp. phoenicea. Tylko cztery osobniki z populacji subsp. phoenicea należą do taksonu subsp. turbinata. Wskazuje to na różne pochodzenie i długą izolację tych dwóch podgatunków.

Różnice między populacjami subsp. turbinata są istotne, jednakże wiele z przebadanych osobników z tych populacji ma charakter pośredni. Można to wyjaśnić w ten sposób, iż wprawdzie były one izolowane od dawna, ale jednocześnie mają wspólne pochodzenie.

SŁOWA KLUCZOWE: analiza statystyczna, biometria, jałowiec, szyszkojagoda, zróżnicowanie morfologiczne, zmienność. 